\title{
Application of inulin-type fructans in animal feed and pet food
}

\author{
J. M. A. J. Verdonk ${ }^{1 *}$, S. B. Shim ${ }^{2}$, P. van Leeuwen ${ }^{1}$ and M. W. A. Verstegen ${ }^{2}$ \\ ${ }^{1}$ Animal Sciences Group, Wageningen UR, PO Box 65, 8200 AB Lelystad, The Netherlands \\ ${ }^{2}$ Animal Nutrition Group, Department of Animal Science, Wageningen University, Wageningen UR, PO Box 338, 6700 AH Wageningen, \\ The Netherlands
}

\begin{abstract}
The inulin-type fructans are non-digestible oligosaccharides that are fermented in the gastrointestinal tract of farm animals and pets. This review focuses on the various effects of inulin-type fructans in pigs, poultry, calves and companion animals. Effects of the inulin-type fructans on gut microflora, digestion and availability of nutrients, gut morphology, fermentation characteristics and animal performance are discussed. Inulin-type fructans can support animal performance and health by affecting nutrient digestion, gut microflora and gut morphology, although results vary depending on composition of the basal diet, inclusion level, type of fructan, adaptation period and experimental hygienic conditions.
\end{abstract}

Inulin-type fructans: Feed and pet food: Performance and health

For several decades, antibiotics and chemotherapeutics in prophylactic doses have been used in animal feed to improve animal welfare and to obtain economic benefits in terms of improved animal performance and reduced medication costs. However, there are increasing concerns about the risk of developing cross-resistance and multiple-antibiotic resistance in pathogenic bacteria both in man and livestock, linked to the therapeutic and subtherapeutic uses of antibiotics in livestock and pets.

The European Union has banned all in-feed use of antibiotics from 2006 and the use of antibiotics in feed is being considered for elimination (or intense regulation) in other parts of the world. This perspective has stimulated nutritionists and feed manufacturers to search for new, safer alternatives. The primary alternatives studied include acidification of the feed by organic acids, feeding probiotic organisms and feeding prebiotic compounds.

In the 1980s, the possible potential effects of prebiotics in animal feeds was already recognised. Since then, the interest in the use of prebiotics in animal feed and pet food has resulted in extensive research activity. Mul \& Perry (1994; farm and pet animals), Houdijk (1998; swine), Iji \& Tivey (1998, 1999; poultry), Flickinger \& Fahey (2002; pets, poultry, swine and rabbits) and Patterson \& Burkholder (2003; swine) have documented the use of prebiotics in diets for farm animals and pets.

The non-digestible inulin-type fructans are found widely in many vegetable feed and food ingredients and are perhaps the best studied and documented prebiotics in domesticated animals (Flickinger et al. 2003a).

The aim of this review is to provide an overview of recent developments on the use and application of inulin-type fructans in livestock feed and pet food including effects on intake, digestion and availability of nutrients; gut microflora and morphology; immunity and health; and performance in farm animals and pets.

\section{Application of inulin-type fructans in diets for pigs (Table 1)}

Weaning is a stressful event for pigs. Under commercial conditions, weaning piglets often face nutritional, social and psychological stress. As a result, abrupt weaning is typically accompanied by low feed intake. Weaning also causes morphological and histological changes of the small intestine of pigs resulting in maldigestion and malabsorption. When feed intake increases, enterotoxaemic bacteria may proliferate causing diarrhoea. Diarrhoea frequently occurs after the weaning transition (Nabuurs, 1991). Supplementing inulin-type fructans to weaning diets may be a practical strategy to reduce weaning-related transition of intestinal microflora by supporting beneficial bacteria such as bifidobacteria and lactobacilli and thereby decreasing intestinal pathogens like Escherichia coli.

Patterson \& Burkholder (2003) and Flickinger et al. (2003a,b) summarised several experiments in which different types of fructans and other prebiotics were supplied in solid feed, formula or drinking-water to pigs alone or in combination with a probiotic. The effects of inulin-type fructans were categorised by the effect on performance; availability, digestion and retention of nutrients; gut microflora; host defence; and gut integrity. Reported effects on performance of pigs varied from little to no effect (Farnworth et al. 1992; Howard et al. 1993; Olsen \& Maribo, 1999), and from mixed (Houdijk et al. 1998) to stimulating effects (Russell et al. 1996; Shim \& Choi, 1997; Estrada et al. 2001; He et al. 2002; SB Shim, IH Williams and MWA Verstegan, unpublished results). Supplementation of inulin-type fructans to the diet or drinking-water resulted in fewer cases of 


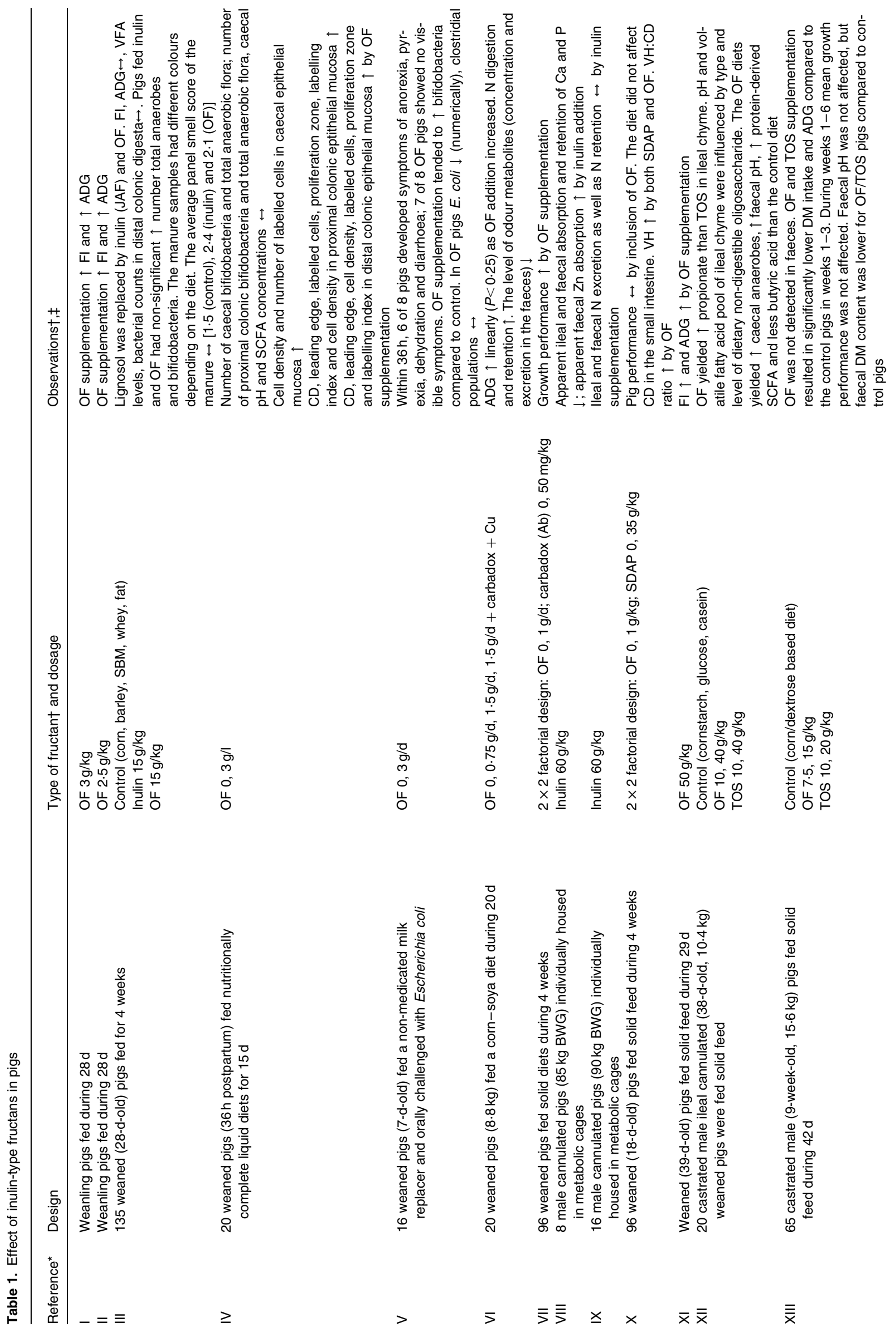




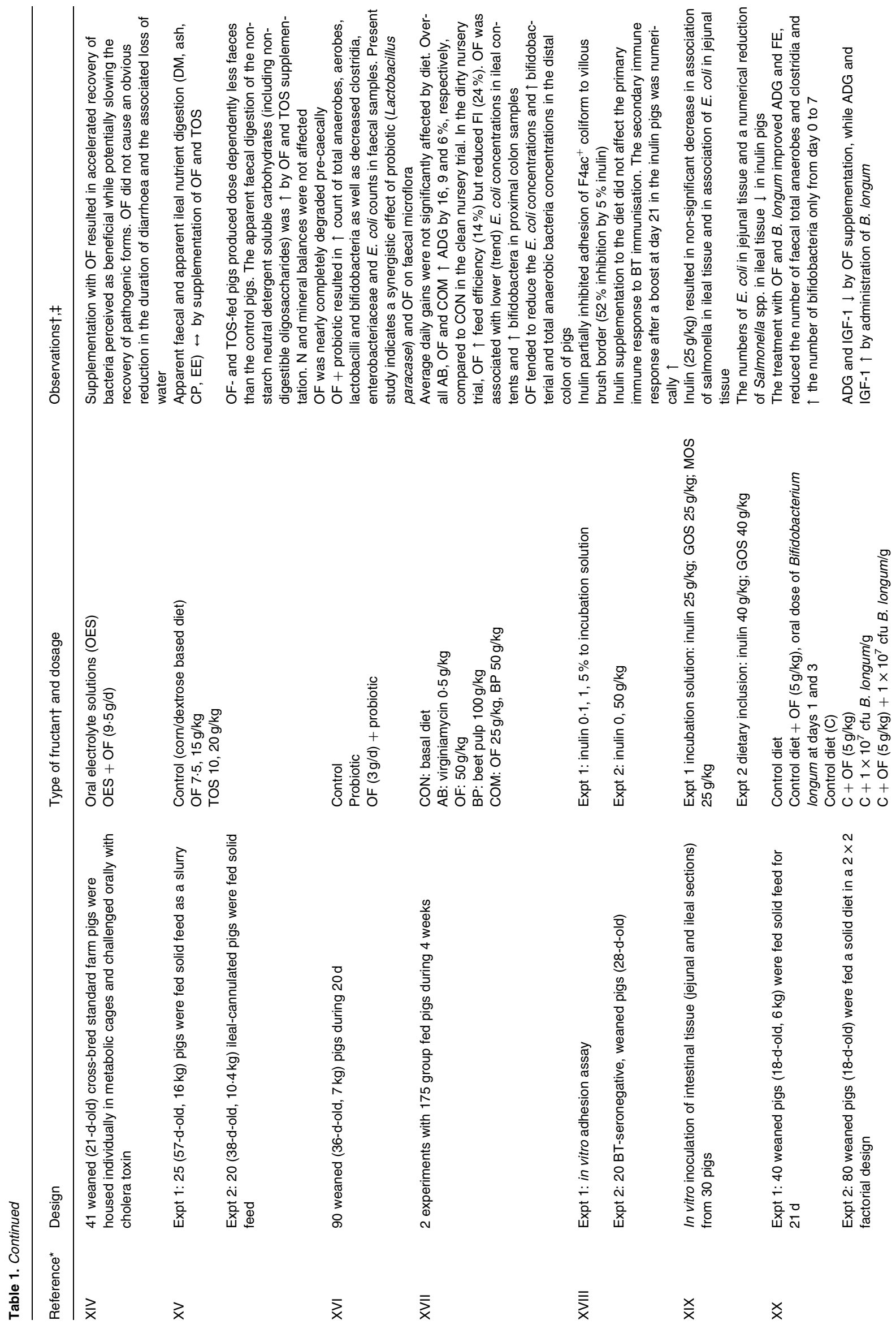




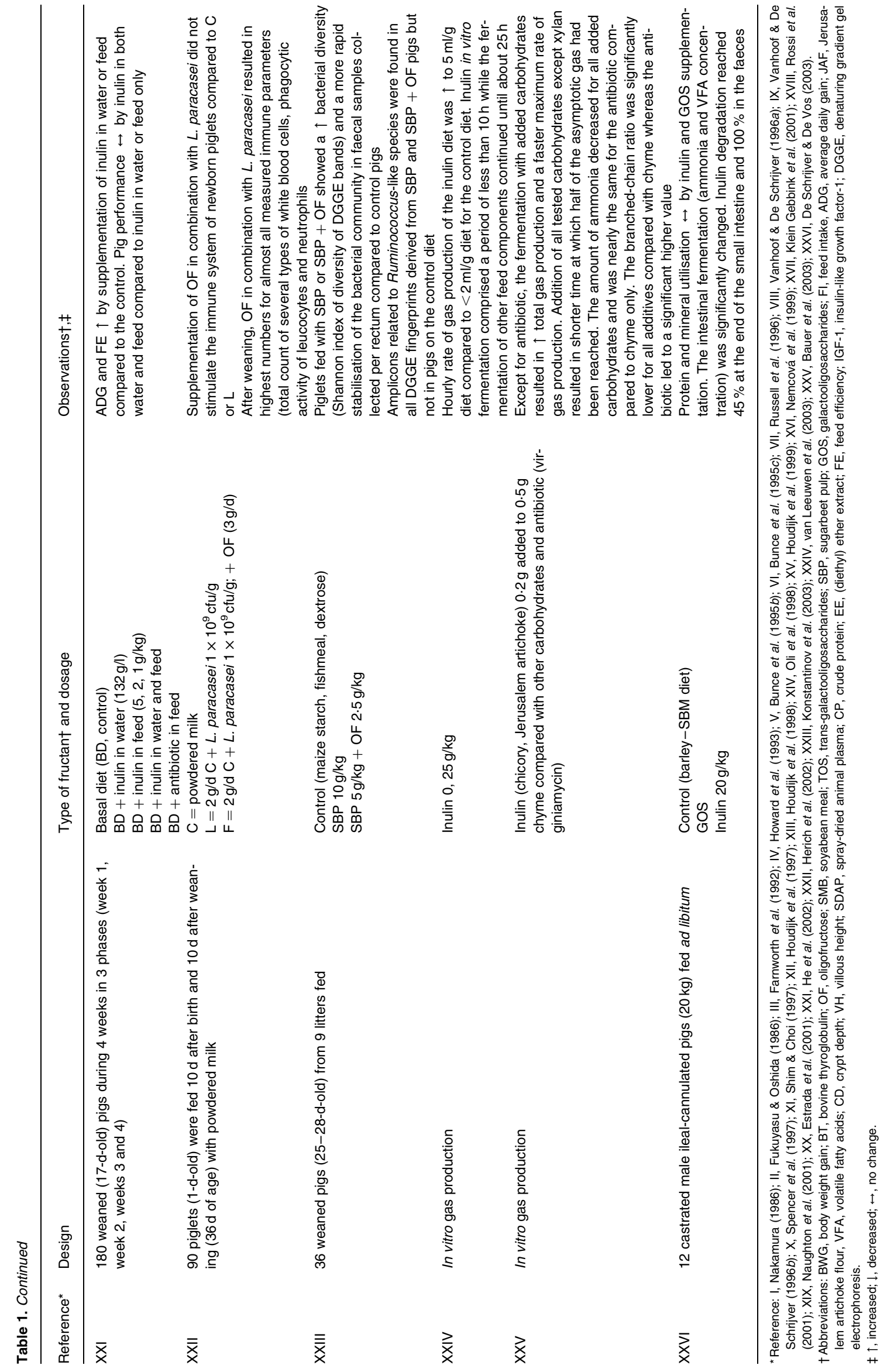


diarrhoea, reduced mortality and decreased number of pigs shedding the pathogen (Bunce et al. 1995b; Oli et al. 1998) compared to controls.

There is scarce information on the effect of inulin and oligofructose $(\mathrm{OF})$ on nutrient digestion, availability and retention. Studies by Vanhoof \& De Schrijver (1996b), Houdijk et al. (1999) and De Schrijver \& De Vos (2003) showed that OF and inulin supplementation does not affect protein digestion and nitrogen retention. Mineral absorption and retention was not affected by inulin or OF except for $\mathrm{Zn}$ (Vanhoof \& De Schrijver, 1996a; Houdijk et al. 1999; De Schrijver \& De Vos, 2003) and Fe (De Schrijver \& De Vos, 2003).

A number of studies have attempted to investigate the effect of inulin-type fructans on intestinal and faecal microbial populations and in vitro gut tissue association. Some studies in pigs evaluating (a limited number of) bacterial populations showed that supplementation had little effect on size and activity of microbial populations (Farnworth et al. 1992; Houdijk et al. 1997). Some studies found enhanced intestinal bifidobacteria populations (Howard et al. 1993; Klein Gebbink et al. 2001). Others reported modulation of the intestinal flora (Nemcová et al. 1999) and speeding up of recovery of the normal intestinal microflora following acute diarrhoea (Oli et al. 1998). Konstantinov et al. (2003) studied the changes in time of the predominant faecal bacterial community in weaning pigs that were fed diets containing inulin-type fructans and/or sugarbeet pulp using denaturing gradient gel electrophoresis (DGGE) analysis, which is used to describe the microbial diversity in complex ecosystems including the mammalian intestinal tract. Piglets fed diets containing sugarbeet pulp $(10 \mathrm{~g} / \mathrm{kg})$ or inulin-type fructans + sugarbeet pulp $(2 \cdot 5+5 \mathrm{~g} / \mathrm{kg})$ showed a higher bacterial diversity and a more rapid stabilisation of the bacterial community compared with that of the animals fed the control diet (maize starch).

Recently, some experiments have also demonstrated that inulin-type fructans affect in vitro fermentation kinetics when used as a substrate (Houdijk, 1998; Bauer et al. 2003; van Leeuwen et al. 2003) or affects the inoculum when included in the diet (Houdijk, 1998).

Only a few studies describe the effect of inulin-type fructans on the host defence system and gut integrity. Herich et al. (2002) demonstrated that the combination of $\mathrm{OF}$ and probiotics given to pigs before and after birth increased the number of $\mathrm{CD}^{+}$ T-lymphocytes compared to the control diet.

Inulin reduced the in vitro association of E. coli to jejunal organ tissue and of Salmonella spp. (non-significant) to ileal tissue (Naughton et al. 2001). Rossi et al. (2001) showed that inulin reduced the in vitro adhesion of a pathogenic coliform to intestinal porcine mucosa. Results also suggested a systemic specific immunomodulatory effect of inulin in immunisation against bovine thyroglobulin.

Howard et al. (1993) concluded that OF improved the morphological and the cellular kinetics of the epithelial mucosa in the large intestine. Spencer et al. (1997) investigated the effect of supplementation of spray-dried animal plasma and inulin-type fructans on the morphology of the small intestine in weaned pigs. Inulin-type fructans did not affect crypt depth but did increase the villous height and villous height:crypt depth ratio.

Shim et al. (SB Shim, IH Williams and MWA Verstegen, unpublished results) found that OF supplementation (2.5 and $30 \mathrm{~g} / \mathrm{kg}$ ) for 3 weeks post-weaning (numerically) increased villous height but not crypt depth in the small intestine of pigs compared to the control. Brush border enzyme activity was not affected.

\section{Application of inulin-type fructans in diets for poultry (Table 2)}

At hatching, the gastrointestinal tract of broilers is sterile. Immediately, bacteria originating from the mother, the environment or the diet will colonise in the gastrointestinal tract. In case of mother contacts, a diverse microbial population will enter the gastrointestinal tract. As a result, after the first colonisation, bacterial species coming later in time will have greater difficulty colonising (colonisation resistance) than the initial population. Because of the strict separation of generations in broiler chickens, any bacteria from the environment might colonise (e.g. attach to intestinal binding sites or multiply faster than being removed via chyme passage) the intestinal tract. Those feed components that are resistant to enzymatic degradation, such as inulin-type fructans, serve as a substrate for bacterial activity in the intestinal lumen. The interaction between host nutrition and the intestinal microbiota has been clearly illustrated using germ-free animals. Langhout (1998) clearly showed the importance of controlling the activity of the intestinal microbiota to support gut integrity and to avoid (i) bacterial overgrowth, (ii) reduced nutrient digestibility and (iii) reduced production performance.

Feeding inulin-type fructans may be a practical strategy for controlling pathogenic bacteria in chickens. Flickinger \& Fahey (2002) and Flickinger et al. (2003a) summarised several experiments in which different types of fructans were fed to broilers alone or in combination with a probiotic to evaluate the effect on colonisation of pathogens (i.e. Salmonella spp. and Campylobacter jejuni) in caeca (Bailey et al. 1991; Oyarzabal \& Conner, 1996; Chambers et al. 1997; Fukata et al. 1999) and on prechilled poultry carcasses. Researchers concluded that supplementation of inulin-type fructans in combination with competitive exclusion flora may reduce colonisation by the pathogenic bacteria.

In recent experiments with broilers, we (Verdonk \& van Leeuwen, 2004) evaluated the effect of supplementation of inulin-type fructans on the colonisation and shedding of pathogens. The first broiler study evaluated the effect of the inclusion of $20 \mathrm{~g}$ OF and inulin $/ \mathrm{kg}$ feed on the colonisation and shedding of Salmonella typhimurium and $C$. jejuni in broilers. The broilers were fed one of four dietary treatments and challenged in the crop on days 10 and 11 of age with a low or high dose of $S$. typhimurium and a single dose of $C$. jejuni. The birds were housed in threetier battery cages. Feed intake and body weight were measured at ages 9, 14, 21 and $35 \mathrm{~d}$. During dissection of birds on days 14, 21 and 35, digesta samples of the crop and caeca were taken and the colonisation was determined. On days 18 and 28 , salmonella shedding via the excreta was measured.

The second study evaluated the effect of inulin at four inclusion levels in a basal diet on the occurrence of lesions due to Eimeria acervulina and Clostridium perfringens. The broilers were housed in floor pens and given an E. acervulina challenge orally at day 10 of age, followed by an oral inoculation of $\mathrm{Cl}$. perfringens on days 14,15 and 16. Intestinal lesions for coccidiosis and necrotic enteritis in the duodenum and jejunum on days $15-17$ and 22 were scored visually.

The supplementation of inulin-type fructans in the diet stimulated the performance of young broiler chickens, but did not clearly affect the colonisation and shedding of S. typhimurium and $C$. jejuni or the occurrence of lesions due to E. acervulina and $\mathrm{Cl}$. perfringens. 


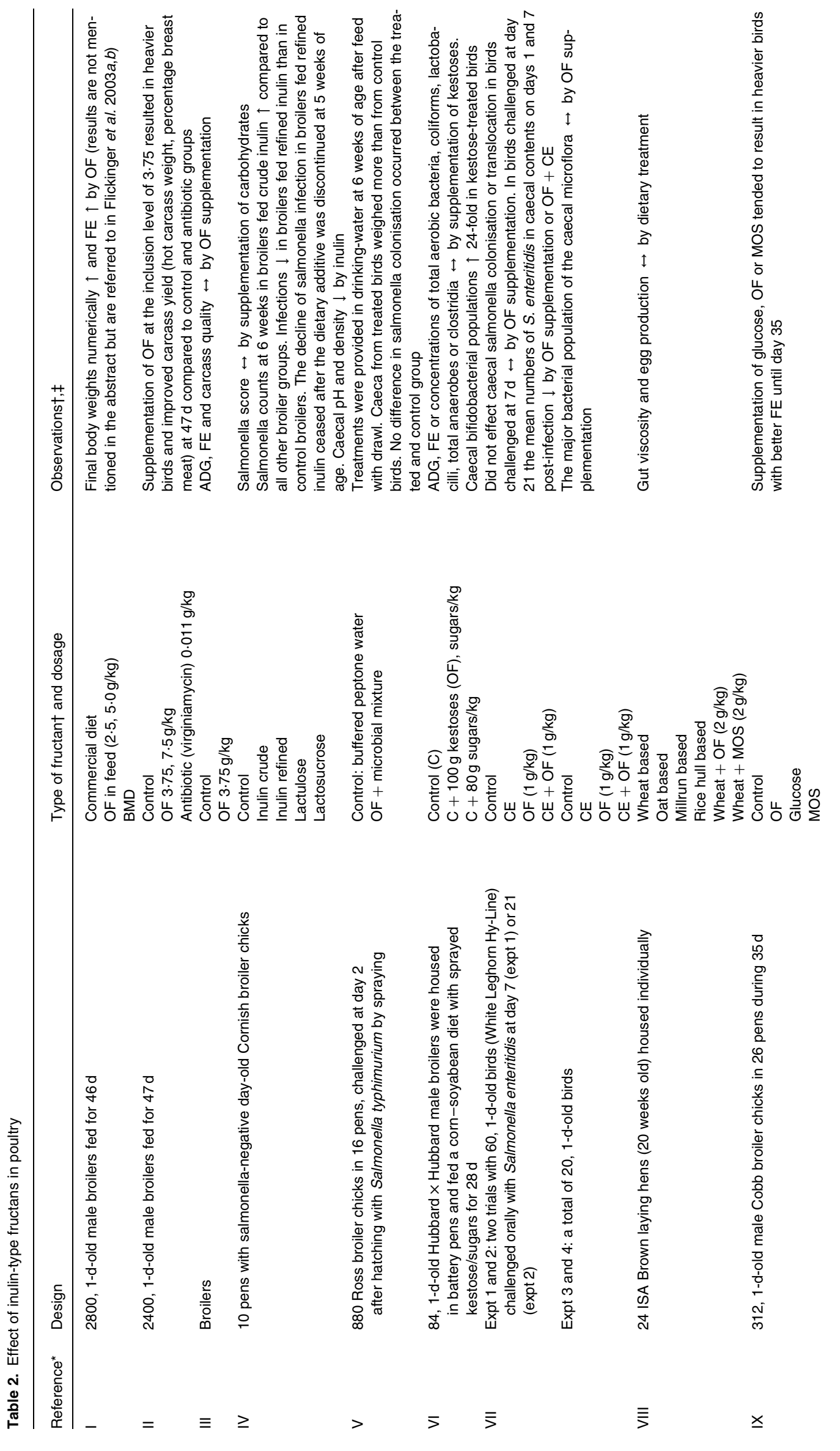


Prebiotics in feed and pet food

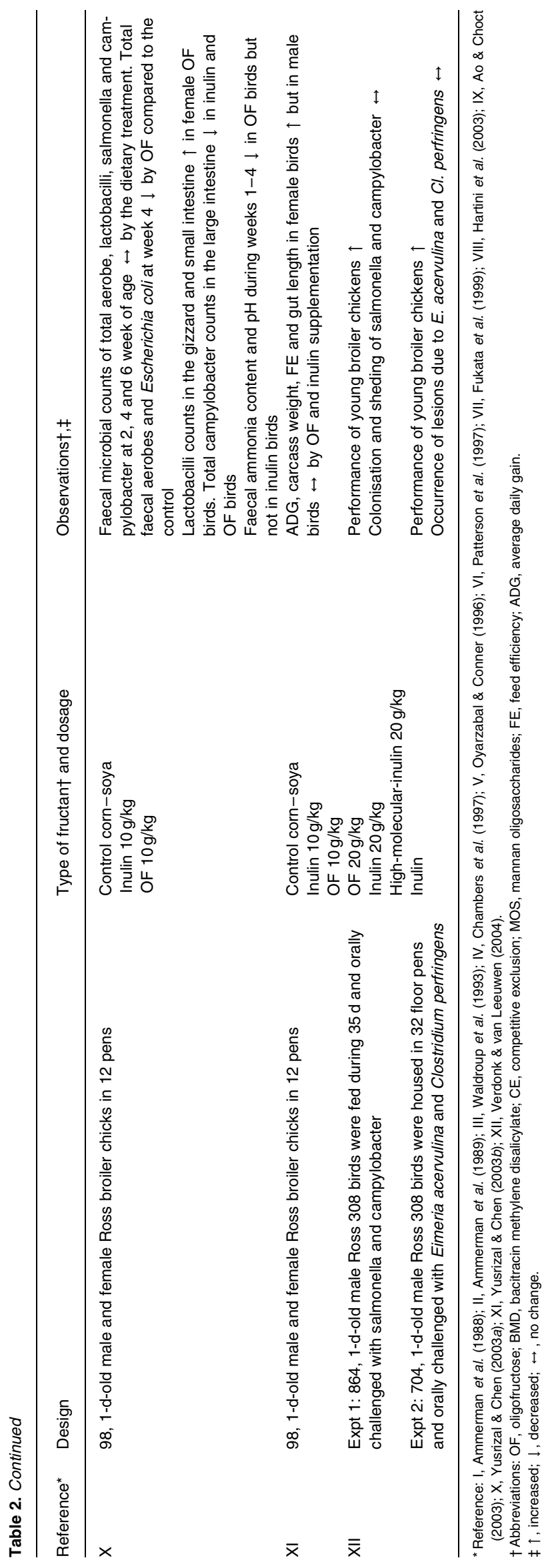


Yusrizal \& Chen (2003a) reported that supplementation of OF and inulin $(10 \mathrm{~g} / \mathrm{kg})$ to a corn-soya diet did not affect the faecal microbial counts of total aerobe, lactobacilli, salmonella and campylobacter in broilers at 2, 4 and 6 weeks of age. OF resulted in significant reductions in total faecal aerobes and E. coli at week 4 compared to the control. It also increased the lactobacilli counts in the gizzard and small intestine of female broilers. Inulin or OF supplementation reduced total campylobacter counts in the large intestine. OF but not inulin resulted in reduced faecal ammonia content and pH during weeks 1 through 4 . The same authors (Yusrizal \& Chen, 2003b) reported that supplementation of $\mathrm{OF}$ and inulin improved body weight gain, carcass weight, feed conversion efficiency and gut length in female birds but not in male birds. Also, Ao \& Choct (2003) reported that birds given drinking-water supplemented with OF (0.05\%) were heavier and had more efficient feed conversion at day 35 compared to the control birds. Recently, Hartini et al. (2003) concluded that supplementation of inulin-type fructans $(2 \mathrm{~g} / \mathrm{kg})$ to a wheat-based diet did not affect the feed intake nor egg production in ISA Brown laying hens.

\section{Application of inulin-type fructans in diets for (preruminant) calves (Table 3)}

The common practice of early weaning of preruminant calves for veal production, followed by long distance transport and regrouping of animals from different origins, may cause a challenge to the natural defence system resulting in dysbacteriosis and digestive disorders. In many fattening systems, starter treatments with antibiotics have become common practice. Mul \& Perry (1994) mentioned a large-scale use of inulin-type fructans resulting in similar fattening results compared to the in-feed antibiotics. Verdonk \& van Leeuwen (2004) have evaluated the effect of inclusion of inulin-type fructans in the milk replacer on health and production performance of preruminant calves during the first 3 weeks after arrival at the fattening farm. Four groups of eight calves, housed individually in wooden boxes with a slatted floor, were fed the basal calf milk replacer supplemented with $20 \mathrm{~g}$ of dextrose, OF, inulin or dextrose supplemented with antibiotics $/ \mathrm{kg}$. Individual body weight of the calves was determined at $7 \mathrm{~d}$ intervals and feed intake was measured per calf per feeding. The faecal consistency scores were conducted daily. The composition of the microflora in rectal samples was determined by DGGE and nucleotide sequence analysis of rDNA. During the 3-week experimental period, the $\mathrm{OF}$ and the antibiotics groups resulted in higher $(P<0.05)$ body weight gain compared to the dextrose group. The faeces consistency over the observed period was best $(P>0.05)$ in the OF group and worse in the dextrose group. The DGGE gels revealed that the faecal flora in young milk-fed calves in fattening farms is very unstable. The dietary treatment did not affect the pattern or the shift in pattern of the bands in the gels of the faecal samples. Analysis of ileal contents and faeces showed that some $70 \%$ of the dietary inulin-type fructans reached the caecum but that no fructans were recovered in the faeces.

Kaufhold et al. (2000) supplemented 10-week-old calves (average body weight $117 \mathrm{~kg}$ ) with 0 or $10 \mathrm{~g} \mathrm{OF} / \mathrm{d}$ (with the morning meal). Feed intake was similar between groups but weight gain tended to be higher for the OF-supplemented group. They concluded that $\mathrm{OF}$ had basically similar effects on the metabolic and endocrine traits such as concentration of glucose, lactate, triacylglycerols and insulin in blood in preruminant calves as in animals and human subjects with diabetes mellitus.

Webb et al. (1992) observed greater weight gains in Holstein bull calves $(3-5 \mathrm{~d}$ old $)$ by adding a combination of inulin-type fructans $(3.75 \mathrm{~g} / \mathrm{kg})$, sodium diacetate $(10 \mathrm{~g} / \mathrm{kg})$ and decoquinate $(50 \mathrm{mg} / \mathrm{kg})$ into the milk replacer and starter grain compared with supplementing the milk replacer with sodium diacetate and decoquinate alone. Unfortunately, the effects on rumen and gut microflora were not studied.

Donovan et al. (2002) reported that supplementation of a blend of inulin-type fructans, allicin and gut-active microbes to the milk replacer had similar effects to those of the antibiotics-supplementation fed to Holstein male and female calves.

Compared with diets for other species, dietary proteins and carbohydrates for veal calves are usually highly digestible. This was to a large extent related to the soluble/dispersible nature of the proteins used in veal calf diets. Commercial milk replacers were initially made based primarily on skimmed milk powder and animal fat. During the last decade, replacement of milk proteins and lactose by vegetable proteins and carbohydrates has become an important issue both in practice and research (Verdonk et al. 2002). Increasingly, part of the dietary lactose is being replaced by starch and by soya oligosaccharides. Up to $15 \%$ starch can be added to veal calves' diets, with only a minor decrease in starch digestibility. At higher levels (15-25\%), the decrease in starch digestibility is more pronounced (van Weerden et al. 1967; van der Honing et al. 1974) and this causes increased fermentation in the large gut. Visual characteristics and $\mathrm{pH}$ of the faeces were affected by the quantity of starch fermented in the hindgut. We have demonstrated (Verdonk et al. 1998) that replacement of lactose $(65 \mathrm{~g} / \mathrm{kg})$ by soluble or insoluble soya carbohydrates resulted in significantly decreased apparent ileal digestibility of DM, crude ash and $\mathrm{N}$-free extract. Inclusion of the soya carbohydrates in the diet also tended to increase the endogenous flow of $\mathrm{N}$ at the terminal ileum. It was suggested that this increase might be caused by fermentation in the small intestine increasing the flow of bacterial $\mathrm{N}$ to the large gut. Inulin-type fructans may play a role in creating and maintaining a desired, stable microflora in the rumen (supplementation to solid feed), and the small and large gut (supplementation to milk replacer) of (preruminant) calves.

\section{Application of inulin-type fructans in pet foods (Table 4)}

Several reasons that justify the addition of OF and inulin in pet foods are as follows (Flickinger et al. 2003a):

- manipulating the composition of the intestinal flora,

- stimulating gut integrity,

- affecting nitrogen metabolism, and

- reducing offensive faecal odour.

Furthermore, it was indicated that the geriatric pet population is more prone to intestinal irregularities and has diminished digestive microbial balance when compared to younger animals. In their review, Flickinger et al. (2003a) summarise the results of studies indicating an effect of supplementation of inulin-type fructans on the intestinal microflora, epithelial cell proliferation, faecal characteristics and nutrient digestibilities.

Recently, Hesta et al. (2001) studied the effect of supplementation of OF $(30,60,90 \mathrm{~g} / \mathrm{kg})$ and inulin $(30,60 \mathrm{~g} / \mathrm{kg})$ to a com- 
Prebiotics in feed and pet food

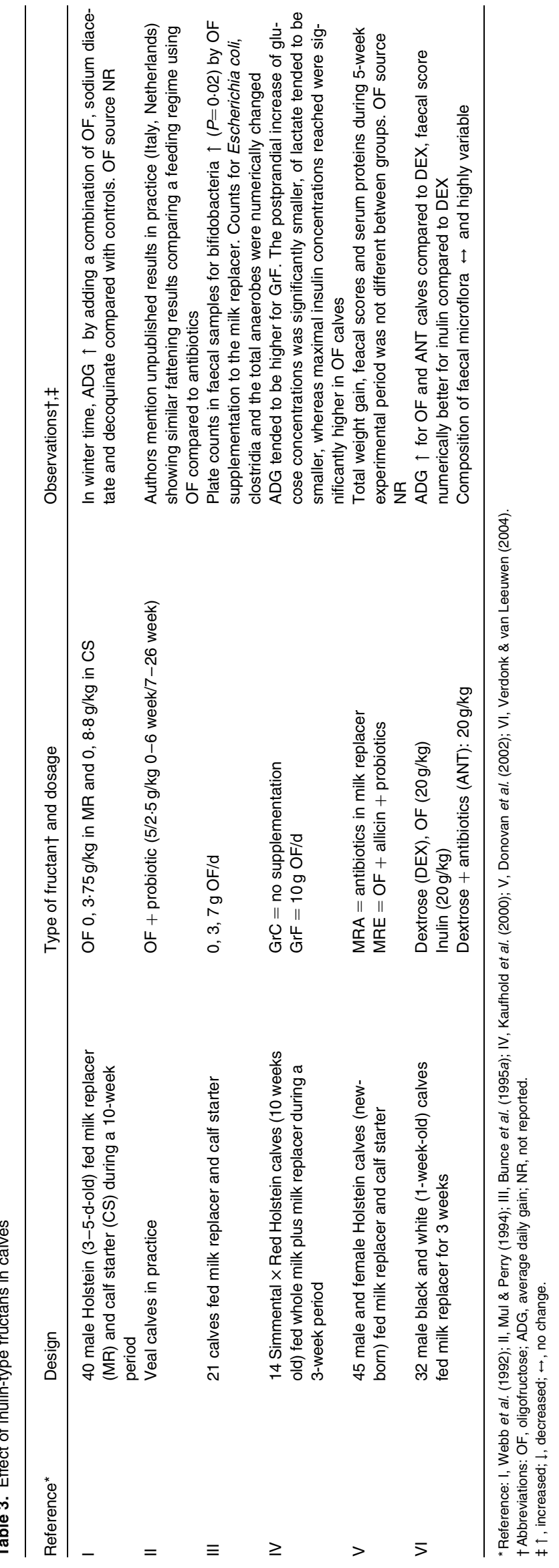




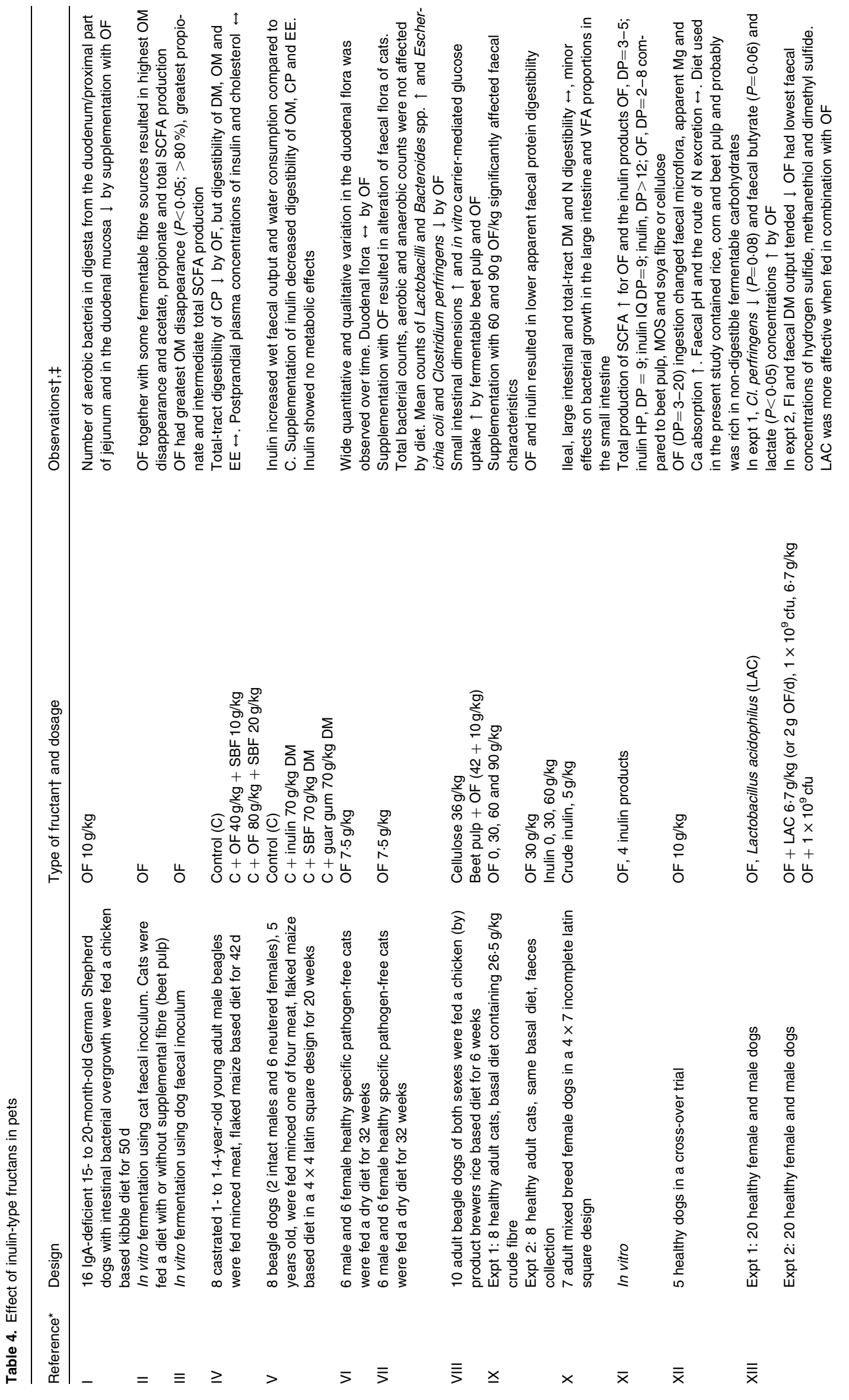




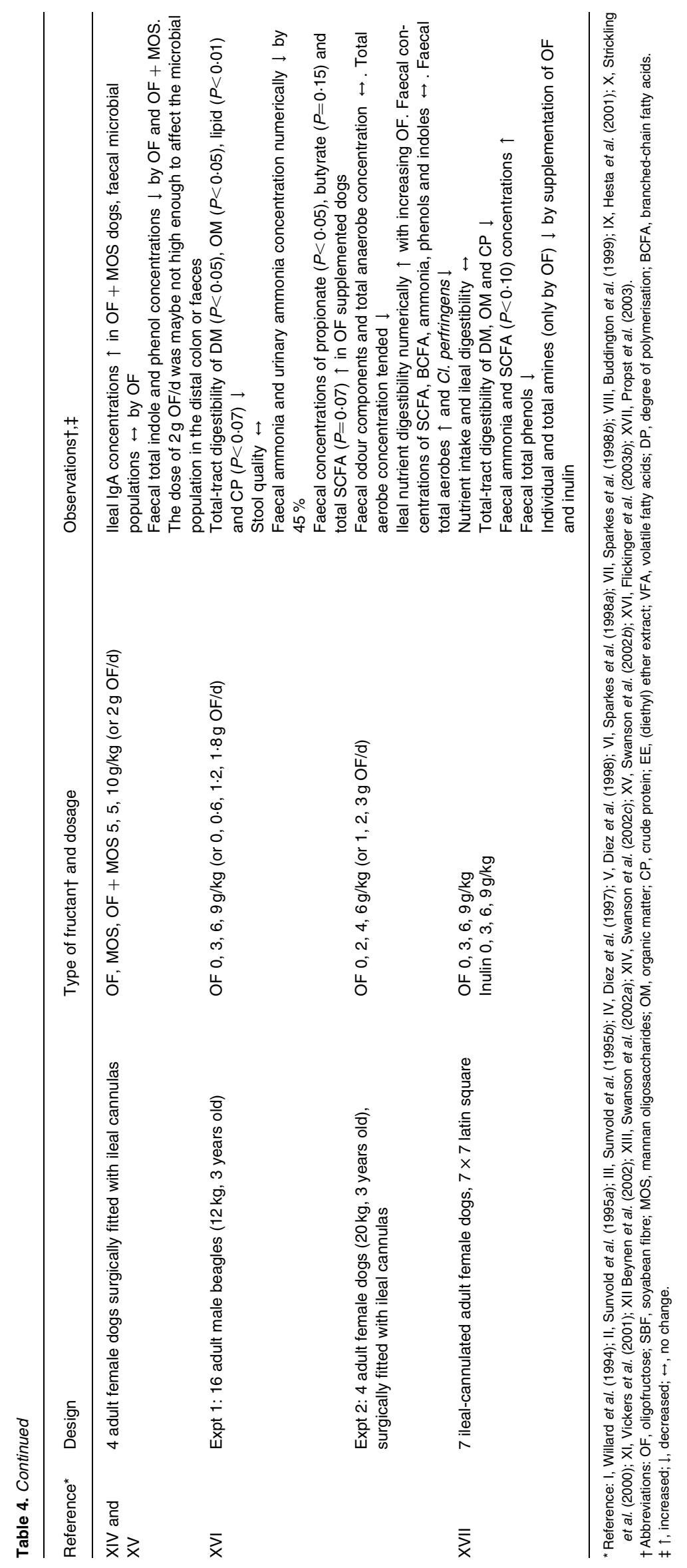


mercial diet in cats. Supplementation of 60 and $90 \mathrm{~g} / \mathrm{kg}$ OF in the diet significantly affected faecal characteristics. Both OF $(30 \mathrm{~g} /$ $\mathrm{kg})$ and inulin $(30,60 \mathrm{~g} / \mathrm{kg})$ resulted in lower apparent faecal protein digestibility. These results contradict Diez et al. (1997), who reported that 40 or $80 \mathrm{~g}$ diet $\mathrm{OF} / \mathrm{kg}$ did not reduce total-tract digestibility of DM, organic matter or ether extract for dogs fed a beef-, corn- and vegetable oil-based diet. However, Diez et al. did report that supplementation with $80 \mathrm{~g} \mathrm{OF} / \mathrm{kg}$ reduced the digestibility of crude protein for supplemented diets compared to the control diet.

At lower inclusion levels of inulin-type fructans $(1-10 \mathrm{~g} / \mathrm{kg})$, results on nutrient digestibility in dogs are conflicting and range from (i) no effect on ileal and total-tract nutrient digestibility (Strickling et al. 2000; Beynen et al. 2002; Grieshop et al. 2002; Swanson et al. 2002b; Propst et al. 2003), (ii) a decreased total-tract nutrient digestibility (Flickinger et al. 2003b; Propst et al. 2003) and (iii) an increased absorption of $\mathrm{Mg}$ and $\mathrm{Ca}$ (Beynen et al. 2002).

\section{Conclusions}

Important issues for pet owners and farmers are (1) animal health and veterinary costs, (2) performance and economics and (3) excretion of nutrients into the environment. Inulin-type fructans may play a role in solving these issues. There are many considerations in supplementing inulin-type fructans in animal feed and pet food. These include the type of diet (i.e. the content of non-digestible oligosaccharides); the type and inclusion level to supplement; the animal characteristics (species, age, stage of production); and the hygienic conditions of the farm.

The number of studies evaluating the potential of inulin-type fructans in animal feed and pet food has increased considerably during the last few years. Studies indicate a generally positive effect on gut microflora, host health (gut integrity, colonisation) and animal performance (digestion, body weight gain, feed efficiency). However, the data on the efficacy of inulin-type fructans are sometimes variable and not yet fully conclusive. Data on the effect of inulin-type fructans on intestinal and systemic immune systems as well as the resistance to infections remain scarce.

Costs of animal production will increase when in-feed antibiotics are banned; thus, there is a need for conclusive data to determine under which conditions inulin-type fructans can reduce the impact of (sub-clinical) infections and support animal performance.

There is a need for more standardised studies using both negative and positive controls to study the efficacy of inulintype fructans. The control groups as well as the experimental setting should be chosen in line with the selected objective of the study; for example, animal performance or nutrient excretion. Both technical and economic parameters should be evaluated to be able to conclude on the effectiveness of fructan supplementation.

In order to effectively supplement inulin-type fructans in feed and pet food, additional research is also needed to elucidate the mode of action and the relationship between gut microflora, gut and animal health, and performance. Molecular DNA techniques might be helpful in future research to gain further insight into the changes occurring in the composition of the gut microflora and the gene expression in gut tissue and relevant organs.

\section{References}

Ammerman E, Quarles C \& Twining PV Jr (1988) Effect of dietary fructo-oligosaccharides on feed efficiency in floor pen-reared male broilers. Poult Sci 67, Suppl., 1.

Ammerman E, Quarles C \& Twining PV Jr (1989) Evaluation of fructooligosaccharides on performance and carcass yield of male broilers. Poult Sci 68, Suppl., 167.

Ao Z \& Choct M (2003) Early nutrition for broilers - a two edged sword? Proc Aust Poult Sci Symp 15, 149-152.

Bailey JS, Blankenship LC \& Cox NA (1991) Effect of fructooligosaccharide on Salmonella colonization of the chicken intestine. Poult Sci 70, 2433-2438.

Bauer E, Williams BA, Voigt C, Mosenthin R \& Verstegen MWA (2003) In vitro studies on the impact of carbohydrate-rich ingredients on fermentation characteristics of chyme obtained from pigs. In Proceedings of the 9th International Symposium on Digestive Physiology in Pigs, vol. 2, pp. 19-21 [RA Ball, editor]. Banff, Canada: University of Alberta.

Beynen AC, Baas JC, Hoekemeijer PE, Kappert HJ, Bakker MH, Koopman JP \& Lemmens AG (2002) Faecal bacterial profile, nitrogen excretion and mineral absorption in healthy dogs fed supplemental oligofructose. J Anim Physiol Anim Nutr 86, 298-305.

Buddington RK, Buddington KK \& Sunvold GD (1999) Influence of fermentable fiber on small intestinal dimensions and transport of glucose and proline in dogs. Am J Vet Res 60, 354-358.

Bunce TJ, Howard MD, Kerley MS \& Allee GL (1995a) Feeding fructooligosaccharides to calves increased bifidobacteria and decreased Escherichia coli. J Anim Sci 73, Suppl. 1, 281.

Bunce TJ, Howard MD, Kerley MS, Allee GL \& Pace LW (1995b) Protective effect of fructooligosaccharide (FOS) in prevention of mortality and morbidity from infectious $E$. coli $\mathrm{K}: 88$ challenge. J Anim Sci 73, Suppl. 1, 69.

Bunce TJ, Kerley MS, Allee GL \& Day BN (1995c) Feeding fructooligosaccharide to weaned pig improves nitrogen metabolism and reduces odor metabolite excretion. J Anim Sci 73, Suppl. 85, 70.

Chambers JR, Spencer JL \& Modler HW (1997) The influence of complex carbohydrates on Salmonella typhimurium colonization, $\mathrm{pH}$, and density of broiler ceca. Poult Sci 76, 445-451.

De Schrijver R \& De Vos S (2003) Effects of dietary supplemented oligosaccharides on digestion in ileal cannulated pigs. In Proceedings of the 9th International Symposium on Digestive Physiology in Pigs, vol. 2, pp. 274-276 [RA Ball, editor]. Banff, Canada: University of Alberta.

Diez M, Hornick JL, Baldwin P \& Istasse L (1997) Influence of a blend of fructo-oligosaccharides and sugar beet fiber on nutrient digestibility and plasma metabolite concentrations in healthy Beagles. Am J Vet Res 58, $1238-1242$.

Diez M, Hornick JL, Baldwin P, Van Eenaeme C \& Istasse L (1998) The influence of sugar-beet fibre, guar gum and inulin on nutrient digestibility, water consumption and plasma metabolites in healthy Beagle dogs. Res Vet Sci 64, 91-96.

Donovan DC, Franklin ST, Chase CCL \& Hippen AR (2002) Growth and health of Holstein calves fed milk replacers supplemented with antibiotics or Enteroguard. J Dairy Sci 85, 947-950.

Estrada A, Drew MD \& van Kessel A (2001) Effect of the dietary supplementation of fructooligosaccharides and Bifidobacterium longum to early-weaned pigs on performance and fecal bacterial populations. Can J Anim Sci 81, 141-148.

Farnworth ER, Modler HW, Jones JD, Cave N, Yamazaki H \& Rao AV (1992) Feeding Jerusalem artichoke flour rich in fructooligosaccharides to weanling pigs. Can J Anim Sci 72, 977-980.

Flickinger EA \& Fahey GC Jr (2002) Pet food and feed applications of inulin, oligofructose and other oligosaccharides. Br J Nutr 87, S297-S300.

Flickinger EA, Schreijen EMWC, Patil AR, Hussein HS, Grieshop CM, Merchen NR \& Fahey GC Jr (2003a) Nutrient digestibilities, microbial populations, and protein catabolites as affected by fructan supplementation of dog diets. J Anim Sci 81, 2008-2018. 
Flickinger EA, Van Loo J \& Fahey GC Jr (2003b) Nutritional response to the presence of inulin and oligofructose in the diets of domesticated animals: a review. Crit Rev Food Sci Nutr 43, 19-60.

Fukata T, Sasai K, Miyamoto T \& Baba E (1999) Inhibitory effects of competitive exclusion and fructooligosaccharide, singly and in combination, on Salmonella colonization of chicks. J Food Prot 62, 229-233.

Fukuyasu T \& Oshida T (1986) Use of Neosugar ${ }^{\circledR}$ in piglets. In: Proceedings of the 3rd Neosugar ${ }^{\circledR}$ Conference, pp. 61-69. Tokyo, Japan.

Grieshop CM, Flickinger EA \& Fahey GC Jr (2002) Oral administration of arabinogalactan affects immune status and fecal microbial populations in dogs. $J$ Nutr 132, 478-482.

Hartini S, Choct M, Hinch G \& Nolan JV (2003) The relationship between physico-chemical properties of fibre and their effects on the gut weight of chickens. Proc Aust Poult Sci Symp 15, 135-139.

He G, Baidoo SK, Yang Q, Golz D \& Tungland B (2002) Evaluation of chicory inulin extracts as feed additive for early-weaned pigs. J Anim Sci 80, Suppl. 1, 81.

Herich R, Revajova V, Levkut M, Bomba A, Nemcová R, Guba P \& Gancarčiková S (2002) The effect of Lactobacillus paracasei and Raftilose P95 upon the non-specific immune response of piglets. Food Agric Immunol 14, 171-179.

Hesta M, Janssens GPJ, Debraekeleer J \& De Wilde R (2001) The effect of oligofructose and inulin on faecal characteristics and nutrient digestibility in healthy cats. J Anim Physiol Anim Nutr 85, 135-141.

Houdijk JGM (1998) Effects of non-digestible oligosaccharides in young pig diets. PhD Thesis, Wageningen Agricultural University.

Houdijk J, Bosch M, Verstegen M \& Tamminga S (1997) Type and level of dietary oligosaccharides change volatile fatty acid composition in ileal chyme of young pigs. In Proceedings of the 7th International Symposium on Digestive Physiology in Pigs, pp. 475-478 [JP Laplace, C Février and A Barbeau, editors]. Saint Malo, France: INRA EAAP Publication 88 .

Houdijk JGM, Bosch MW, Verstegen MWA \& Berenpas EJ (1998) Effects of dietary oligosaccharides on the growth performance and faecal characteristics of young growing pigs. Anim Feed Sci Technol 71, 35-48.

Houdijk JGM, Bosch MW, Tamminga S, Verstegen MWA, Berenpas EJ \& Knoop H (1999) Apparent ileal and total tract nutrient digestion by pigs as affected by dietary non-digestible oligosaccharides. J Anim Sci 77, 148-158.

Howard MD, Kerley MS, Gordon LW, Pace LW \& Garleb KA (1993) Effects of dietary addition of fructooligosaccharide on colonic microflora populations and epithelial cell proliferation in neonatal pigs. $J$ Anim Sci 71, Suppl. 1, 71.

Iji PA \& Tivey DR (1998) Natural and synthetic oligosaccharides in broiler chicken diets. World Poult Sci 54, 129-143.

Iji PA \& Tivey DR (1999) The use of oligosaccharides in broiler diets. In Proceedings of the 12th European Symposium on Poultry Nutrition, pp. 193-201. Veldhoven, The Netherlands: WPSA Dutch Branch.

Kaufhold JN, Hammon HM \& Blum JW (2000) Fructo-oligosaccharide supplementation: effects on metabolic, endocrine and hematological traits in veal calves. $J$ Vet Med Ser A 47, 17-29.

Klein Gebbink GAR, Sutton AL, Williams BA, Patterson JA, Richert BT, Kelly DT \& Verstegen MWA (2001) Effects of oligosaccharides in weanling pig diets on performance, microflora and intestinal health. In Proceedings of the 8th Symposium of Digestive Physiology of Pigs, pp. 269-271 [JE Lindberg and B Ogle, editors]. Uppsala, Sweden: CABI Publishing.

Konstantinov SR, Zhu WY, Williams BA, Tamminga S, de Vos WM \& Akkermans ADL (2003) Effect of fermentable carbohydrates on piglet faecal bacterial communities as revealed by denaturing gradient gel electrophoresis analysis of $16 \mathrm{~S}$ ribosomal DNA. FEMS Microbiol Ecol 43, 225-235.

Langhout DJ (1998) The role of the intestinal flora as affected by nonstarch polysaccharides in broiler chicks. PhD Thesis, Wageningen Agricultural University.

Mul AJ \& Perry FG (1994) The role of fructo-oligosaccharides in animal nutrtition. In Recent Advances in Animal Nutrition, pp. 57-79 [PC
Garnsworthy and DJA Cole, editors]. Nottingham, UK: Nottingham University Press.

Nabuurs M (1991) Etiologic and pathogenic studies on postweaning diarrhea. PhD Thesis, University of Utrecht.

Nakamura K (1986) Application of Neosugar ${ }^{\circledR}$ to piglets and sows. In Proceedings of the 3rd Neosugar ${ }^{\circledR}$ Conference, pp. 71-76. Tokyo, Japan.

Naughton PJ, Mikkelsen LL \& Jensen BB (2001) Effects of nondigestible oligosacchrides on Salmonella enterica serovar Thyphimurium and nonpathogenic Escherichia coli in the pig small intestine in vitro. Appl Environ Microbiol 67, 3391-3395.

Nemcová R, Bomba A, Gancarčiková S, Herich R \& Guba P (1999) Study on the effect of Lactobacillus paracasei and fructooligosaccharides on the faecal microflora in weanling piglets. Berl Munch Tierarztl Wochenschr 112, 225-228.

Oli MW, Petschow BW \& Buddington RK (1998) Evaluation of fructooligosaccharide supplementation of oral electrolyte solutions for treatment of diarrhea: recovery of intestinal bacteria. Dig Dis Sci 43, 138-147.

Olsen LE \& Maribo H (1999) Company products for feed for piglets Igalac, FUT and Bokashi F. In Danish Slaughterhouse Report \#443. Denmark: National Committee for Pig Breeding, Health and Production.

Oyarzabal AA \& Conner DE (1996) Application of direct-fed microbial bacteria and fructooligosaccharides for Salmonella control in broilers during feed withdrawal. Poult Sci 75, 186-190.

Patterson JA \& Burkholder KM (2003) Prebiotic feed additives: rationale and use in pigs. In Proceedings of the 9th International Symposium on Digestive Physiology in Pigs, vol. 1, pp. 319-331 [RA Ball, editor]. Banff, Canada: University of Alberta.

Patterson JA, Orban JI, Sutton AL \& Richards GN (1997) Selective enrichment of bifidobacteria in the intestinal tract of broilers by thermally produced kestoses and effect on broiler performance. Poult Sci 76, 497-500.

Propst EL, Flickinger EA, Bauer LL, Merchen NR \& Fahey GC Jr (2003) A dose-response experiment evaluating the effects of oligofructose and inulin on nutrient digestibility, stool quality, and fecal protein catabolites in healthy adult dogs. J Anim Sci 81, 3057-3066.

Rossi F, Cox E, Goddeeris B, Portetelle D, Wavreille J \& Théwis A (2001) Inulin incorporation in the weaned pig diet: intestinal coliform interaction and effect on specific systemic immunity. In Proceedings of the 8th Symposium of Digestive Physiology of Pigs, pp. 299-301 [JE Lindberg and B Ogle, editors]. Uppsala, Sweden: CABI Publishing.

Russell TJ, Kerley MS \& Allee GL (1996) Effect of fructooligosaccharides on growth performance of the weaned pig. J Anim Sci 74, Suppl. 1, 61.

Shim SB \& Choi JH (1997) Growth of weaned pigs is increased by fructooligosaccharides and isomaltooligosaccharides. In Manipulating Pig Production VI, p. 229 [PD Cranwell, editor]. Werribee, Australia: Australian Pig Science Association.

Sparkes AH, Papasouliotis K, Sunvold G, Werrett G, Clarke C, Jones M, Gruffydd-Jones TJ \& Reinhart G (1998a) Bacterial flora in the duodenum of healthy cats, and effect on dietary supplementation with fructooligosaccharides. Am J Vet Res 59, 431-435.

Sparkes AH, Papasouliotis K, Sunvold G, Werrett G, Gruffydd-Jones EA, Egan K, Gruffydd-Jones TJ \& Reinhart G (1998b) Effect of dietary supplementation with fructooligosaccharides on fecal flora of healthy cats. Am J Vet Res 59, 436-440.

Spencer JD, Touchette KJ, Liu H, Allee GL, Newcomb MD, Kerley MS \& Pace LW (1997) Effect of spray-dried plasma and fructooligosaccharide on nursery performance and small intestinal morphology of weaned pigs. J Anim Sci 75, Suppl. 1, 199.

Strickling JA, Harmon DL, Dawson KA \& Gross KL (2000) Evaluation of oligosaccharide addition to dog diets: influences on nutrient digestion and microbial populations. Anim Feed Sci Technol 86, 205-219.

Sunvold GD, Fahey GC Jr, Merchen NR \& Reinhart GA (1995a) In vitro fermentation of selected fibrous substrates by $\operatorname{dog}$ and cat fecal inoculum: influence of diet composition on substrate organic matter disappearance and short-chain fatty acid production. J Anim Sci 73, $1110-1122$ 
Sunvold GD, Fahey GC Jr, Merchen NR, Titgemeyer EC, Bourquin LD, Bauer LL \& Reinhart GA (1995b) Dietary fiber for dogs: IV. In vitro fermentation of selected fiber sources by dog fecal inoculum and in vivo digestion and metabolism of fiber-supplemented diets. J Anim Sci 73, 1099-1109.

Swanson KS, Grieshop CM, Flickinger EA, Bauer LL, Chow JM, Wolf BW, Garleb KA \& Fahey GC Jr (2002a) Fructooligosaccharides and Lactobacillus acidophilus modify gut microbial populations, total tract nutrient digestibilities and fecal protein catabolite concentrations in healthy adult dogs. $J$ Nutr 132, 3721-3731.

Swanson KS, Grieshop CM, Flickinger EA, Bauer LL, Healy HP, Dawson KA, Merchen NR \& Fahey GC Jr (2002b) Supplemental fructooligosaccharides and mannanoligosaccharides influence immune function, ileal and total tract nutrient digestibilities, microbial populations and concentrations of protein catabolites in the large bowel of dogs. $J$ Nutr 132, 980-989.

Swanson KS, Grieshop CM, Flickinger EA, Merchen NR \& Fahey GC Jr (2002c) Effects of supplemental fructooligosaccharides and mannanoligosaccharides on colonic microbial populations, immune function and fecal odor components in the canine. J Nutr 132, 1717S-1719S.

van der Honing Y, Smits B, Lenis N \& Boeve J (1974) Utilisation of energy and nitrogen from maize and potato starch, pre-gelatinized by physical processing, in milk replacers for veal calves. J Anim Physiol Anim Nutr 33, 141-150.

Vanhoof K \& De Schrijver R (1996a) Availability of minerals in rats and pigs fed non-purified diets containing inulin. Nutr Res 16, 1017-1022.

Vanhoof K \& De Schrijver R (1996b) Nitrogen metabolism in rats and pigs fed inulin. Nutr Res 16, 1035-1039.

van Leeuwen P, Jansman AJM \& Cone JW (2003) Modulation of fermentative properties of dietary fibre based on fermentation characteristics determined with the gas production technique. In Proceedings of the 9th International Symposium on Digestive Physiology in Pigs, vol. 2, pp. 90-92 [RA Ball, editor]. Banff, Canada: University of Alberta.

van Weerden EJ, Spronk L \& van Hellemond KK (1967) Zetmeelfermentatie bij hoge zetmeelgiften aan mest kalveren en de invloed van een enzympreparaat. Landbouwkundig Tijdschrift 79, 333-339.
Verdonk JMAJ \& van Leeuwen P (2004) The application of inulin-type fructans in diets for veal calves and broilers. In Inulin and Oligofructose Feelgood Factors for Health and Well-being, 4th Orafti Research Conference, Paris, 12-13, February 2004, pp. 50-51.

Verdonk JMAJ, Beelen GM, Jansman AJM \& Huisman J (1998) Effect of soya carbohydrate fractions on the ileal digestibility and endogenous flow of nitrogen in veal calves. In Recent Advances of Research in Antinutritional Factors in Legume Seed, pp. 341-343 [AJM Jansman, GD Hill, J Huisman and AFB van der Poel, editors]. Wageningen, The Netherlands: Wageningen Pers EAAP publication 93.

Verdonk JMAJ, Gerrits WJJ \& Beynen AC (2002) Replacement of milk protein by vegetable protein in milk replacer diets for veal calves: digestion in relation to intestinal health. In Nutrition and Health of the Gastrointestinal Tract, pp. 183-198 [MC Blok, HA Vahl, L de Lange, AE van de Braak, G Hemke and M Hessing, editors]. Wageningen, The Netherlands: Wageningen Academic Publishers.

Vickers RJ, Sunvold GD, Kelley RL \& Reinhart GA (2001) Comparison of fermentation of selected fructooligosaccharides and other fiber substrates by canine colonic microflora. Am J Vet Res 62, 609-615.

Waldroup AL, Skinner JT, Hierholzer RE \& Waldroup PW (1993) An evaluation of fructooligosaccharide in diets for broiler chicken and effects on Salmonellae contamination of carcasses. Poult Sci 72, 643-650.

Webb PR, Kelogg DW, McGahee MW \& Johnson ZB (1992) Addition of fructooligosaccharide (FOS) and sodium diacetate (SD) plus decoquinate (D) to milk replacer starter and starter grain fed to Holstein calves. J Dairy Sci 75, 300.

Willard MD, Simpson RB, Delles EK, Cohen ND, Fossum TW, Kolp D \& Reinhart G (1994) Effects of dietary supplementation of fructo-oligosaccharides on small intestinal bacterial overgrowth in dogs. Am J Vet Res 55, 654-659.

Yusrizal \& Chen TC (2003a) Effect of adding chicory fructans in feed on fecal and intestinal microflora and excreta volatile ammonia. Int $J$ Poult Sci 2, 188-194.

Yusrizal \& Chen TC (2003b) Effect of adding chicory fructans in feed on broiler growth performance, serum cholesterol and intestinal length. Int J Poult Sci 2, 214-219. 